\title{
Time and tide
}

\author{
(C) $(\mathbb{0} \Theta$ OPEN ACCESS \\ Our future health and wellbeing depend on the oceans
}

\section{Michael H Depledge professor ${ }^{1}$, Mathew P White senior lecturer ${ }^{1}$, Bruce Maycock professor ${ }^{2}$, Lora E Fleming professor ${ }^{1}$}

${ }^{1}$ European Centre for Environment and Human Health, University of Exeter Medical School, Truro, Cornwall, UK; ${ }^{2}$ School of Public Health, Curtin University, Perth, Australia

The global ocean covers more than $70 \%$ of the Earth's surface, and over half the world's population live in coastal zones. ${ }^{1}$ Billions of people depend on marine ecosystems for their livelihoods, with seafood providing a key source of protein ${ }^{2}$ and micronutrients that form the basis of a healthy diet. ${ }^{3}$ Numerous novel medications have been extracted from marine organisms, ${ }^{4}$ including anti-cancer agents from sponges and algae. ${ }^{5}$ More broadly, the "convalescence" benefits of recreational time at the coast have been recognised by medical professionals for centuries. ${ }^{6}$ Time spent at the coast encourages physical activity, reduces stress, and protects against mental ill health. ${ }^{7}$

Unfortunately, already degraded marine ecosystems are under persistent and growing risk of further damage from microbiological and chemical pollution, overexploitation, and climate change. ${ }^{8}$ Rising $\mathrm{CO}_{2}$ emissions threaten the entire marine ecosystem with acidification ${ }^{3}$ and whole coastal communities with more flooding from storms and rising sea levels ${ }^{9}$, with implications for critical public health infrastructure (eg, fresh water and sewage systems). Changing environmental conditions also encourage the spread of toxic algal blooms. ${ }^{10}$

Chemical threats to health range from the well documented dangers of methylmercury poisoning during fetal development ${ }^{11}$ to toxicity from the complex cocktail of chemicals in the environment, including endocrine disrupting phthalates and perfluoroalkyl substances (PFAS), whose diverse autoimmune effects are especially important for elderly people and those with compromised immune systems. ${ }^{12} 13$ These various health threats are not just occurring in far off places; they affect the lives of millions of people here and now and, directly or indirectly, cause diseases that medical practitioners ultimately have to deal with in their clinics. ${ }^{14}$

The United Nations report Our Oceans, Our Future made it clear in 2017 that achieving good health and wellbeing (sustainable development goal (SDG) 3) depends on SDG 14 (conserve and sustainably use the oceans, seas, and marine resources). ${ }^{15}$ The European Marine Board and others have attempted to bring the environmental science and health communities closer together, both through its Linking Oceans and Human Health initiative ${ }^{16}$ and the inclusion of sessions on oceans and human health in its two most recent quinquennial EurOCEAN conferences (http://www.marineboard.eu).

To date, however, it has had little success. Clinicians and health researchers are essential for unravelling the interconnections between the state of marine ecosystems and health and wellbeing. Encouraging and supporting their participation in this growing field is critical. In an age of greater patient and public awareness, responding to highly vocal concerns over health issues arising from environmental damage is not a luxury but a necessity.

\section{No time to waste}

We must hold policy makers to account. Substantial rapid policy changes are possible, as shown by the response to marine plastic pollution. ${ }^{17}$ However, identifying, monitoring, and communicating the risks to human health and wellbeing from the degradation of our seas and oceans has so far not been sufficient to put them firmly on the political and global health agendas for action.

For instance, although fisheries destruction and ocean acidification were discussed extensively in the 2015 Lancet Commission on Planetary Health, ${ }^{2}$ the more recent Lancet Commission on Pollution and Health ${ }^{11}$ and World Health Organization health and climate change ${ }^{18}$ reports, barely mention marine issues specifically. In a world of multiple health threats and challenges, it is understandable if medical practitioners and policy makers focus on the most immediate problems they face, such as cardiovascular disease, diabetes, and depression. Given that practitioners have a "limited pool of worry," ${ }^{19}$ we need to better understand and communicate the opportunities for health promotion that healthy marine environments offer, as well as the loss of current (underappreciated) benefits that will occur with increasing degradation. 
Insights gained over the past 100 years tell us that what has been good for humanity in the short term has often been detrimental to the rest of the planet in the longer term, including the global ocean. ${ }^{20}$ We cannot continue to discharge vast amounts of waste materials into our seas and expect human health and wellbeing to be unaffected. As yet we lack a clear, global vision of how to reconcile the health of both oceans and people, and how to support decision makers in achieving sustainable marine ecosystems that promote public health. Global governance will be required to deliver these aspirations. This might, for example, involve establishing a panel similar to the Intergovernmental Panel for Climate Change to gather evidence and promote collaborative action.

With the decade of the ocean for sustainable development (2021-30) only 18 months away, we must accelerate research into the health risks of our rapidly changing oceans and exploit more fully all existing opportunities to use coastal areas to improve public health. It is not too late for medical practitioners and the health community to make their essential contribution. The current and future state of the global ocean will in large part determine the current and future sustainability, health, and wellbeing of everyone. Although coastal communities are on the front line, ultimately we are all affected by the seas around us.

Competing interests: We have read and understood BMJ policy on declaration of interests and have no relevant interests to declare.

Provenance and peer review: Commissioned, not externally peer reviewed.

1 Martinez ML, Intralawan A, Vazquez G, Perez-Maqueo O, Sutton P, Landgrave R. The coasts of our world: ecological, economic and social importance. Ecol Econ 2007;63:254-7210.1016/j.ecolecon.2006.10.022

2 Whitmee S, Haines A, Beyrer C, etal . Safeguarding human health in the Anthropocen epoch: report of the Rockefeller Foundation-Lancet Commission on planetary health. Lancet 2015;386:1973-2028. 10.1016/S0140-6736(15)60901-1 26188744

3 Lai HT, de Oliveira Otto MC, Lemaitre RN, etal . Serial circulating omega 3 polyunsaturated fatty acids and healthy ageing among older adults in the Cardiovascular Health Study: prospective cohort study. BMJ 2018;363:k4067. 10.1136/bmj.k4067 30333104
4 Gerwick WH, Moore BS. Lessons from the past and charting the future of marine natural products drug discovery and chemical biology. Chem Biol 2012;19:85-98. 10.1016/j.chembiol.2011.12.014 22284357

5 Ercolano G, De Cicco P, lanaro A. New drugs from the sea: pro-apoptotic activity of sponges and algae derived compounds. Mar Drugs 2019;17:31. 10.3390/md17010031 30621025

6 Fortescue Fox R, Lloyd WB. Convalescence on the coast. Lancet 1938;232:37-9. 10.1016/S0140-6736(00)88021-6 .

7 Gascón M, Zijlema W, Vert C, White MP, Nieuwenhuijsen MJ. Outdoor blue spaces, human health and well-being: A systematic review of quantitative studies. Int J Hyg Environ Health 2017;220:1207-21. 10.1016/j.jijheh.2017.08.004 28843736

8 Depledge MH, Lovell R, Wheeler BW, Morrissey KM, White MP, Fleming LE. Future of the sea: health and well-being of coastal communities. UK Government Office for Science, 2017.

9 Neumann B, Vafeidis AT, Zimmermann J, Nicholls RJ. Future coastal population growth and exposure to sea-level rise and coastal flooding - a global assessment. PLoS One 2015;10:e0118571. 10.1371/journal.pone.0118571 25760037

10 Paerl HW, Huisman J. Climate. Blooms like it hot. Science 2008;320:57-8. 10.1126/science.1155398 18388279

11 Landrigan PJ, Fuller R, Acosta NJR, etal . The Lancet Commission on pollution and health Lancet 2018;391:462-512. 10.1016/S0140-6736(17)32345-0 29056410

12 Depledge MH, Tyrrell J, Fleming LE, Holgate ST. Are marine environmental pollutants influencing global patterns of human disease? Mar Environ Res 2013;83:93-5. 10.1016/.jmarenvres.2012.10.003 23140902

13 Fair PA, Wolf B, White ND, etal . Perfluoroalkyl substances (PFASs) in edible fish species from Charleston Harbor and tributaries, South Carolina, United States: Exposure and risk assessment. Environ Res 2019;171:266-77. 10.1016/.jenvres.2019.01.021 30703622

14 Fleming LE, Maycock B, White MP, Depledge MH. Fostering human health through ocean sustainability in the 21st century. People Nat 2019;00:1-810.1002/pan3.10038.

15 UN Secretary General. Draft resolution submitted by the President of the General Assembly: Our ocean, our future: Call for action. 30 June 2017.https://digitallibrary.un. org/record/1290893/files/A_71_L-74-EN.pdf

16 Moore MN, Baker-Austin C, Depledge MH, et al. Linking oceans and human health: a strategic research priority for Europe. Marine Board Position Paper 19. 2013. http:// marineboard.eu/publication/linking-oceans-and-human-health-strategic-research-priorityeurope

17 Science Advice for Policy by European Academies. A scientific perspective on microplastics in nature and society. SAPEA, 2019. https://www.sapea.info/wp-content/uploads/report.pd

18 World Health Organisation. COP24 special report: health and climate change, 2018. https: //www.who.int/globalchange/publications/COP24-report-health-climate-change/en/

19 Centre for Research on Environmental Decisions. The psychology of climate change communication: A guide for scientists, journalists, educators, political aides, and the interested public. 2009.

20 Rockström J, Steffen W, Noone K, etal . Planetary boundaries: exploring the safe operating space for humanity. Ecol Soc 2009;14:3210.5751/ES-03180-140232 .

Published by the BMJ Publishing Group Limited. For permission to use (where not already granted under a licence) please go to http://group.bmj.com/group/rights-licensing/ permissionsThis is an Open Access article distributed in accordance with the Creative Commons Attribution Non Commercial (CC BY-NC 4.0) license, which permits others to distribute, remix, adapt, build upon this work non-commercially, and license their derivative works on different terms, provided the original work is properly cited and the use is non-commercial. See: http://creativecommons.org/licenses/by-nc/4.0/. 